\title{
THE CURRENT STATE OF APPLYING SPACE TECHNOLOGIES TO MONITOR LAND USE EFFICIENCY
}

\author{
๑ 2019 SKYDAN O. V., DANKEVYCH V. Y., DANKEVYCH Y. M.
}

UDC 681.518.3:528

JEL Classification: Q13; R52

\author{
Skydan O. V., Dankevych V. Y., Dankevych Y. M. \\ The Current State of Applying Space Technologies to Monitor Land Use Efficiency
}

The aim of the article is to study the current state of applying space technologies to monitor land use efficiency. It is proved that under conditions of globalization of the world economy there takes place digitalization and automation of production processes with the application of space technologies and many other innovative transformations that should be considered when carrying out economic activities, especially in agriculture. It is justified that the further development of agriculture and agricultural land use should be planned in accordance with the innovation development strategy, which envisages: increase in the contribution of science and technology to the advancement of land economics; use of space technologies to monitor land use efficiency; enhancement of competitiveness of products on the world market through the modernization and automation of production facilities; widespread adoption of remote sensing technologies. It is established that one of the areas in attracting innovative developments is modern space technologies. The current state of and trends in applying space technologies to monitor land use efficiency are considered at the enterprise and state levels. The introduction of modern space technologies for monitoring land use (EOS Crop Monitoring, GIS Data) in Ukraine is analyzed. It is proved that the application of satellite monitoring makes it possible to accurately estimate the crop areas, monitor the condition of plants at all phases of growth, predict the yield at early stages, control agricultural operations, etc. The access to satellite data for previous years and analysis of huge amounts of information using the latest technologies allow assessing the value of land. There identified prospective land use sectors where modern space technologies should be applied, namely: filling the State Land Cadastre, taking land inventory, forming land resource databases. Practical recommendations on the application of space technologies for monitoring land use efficiency, crop forecasting and pricing analysis based on the experience of the EU and the USA are proposed.

Keywords: agricultural production, land resources, space technologies, monitoring, globalization, efficiency, GIS technologies.

DOI: https://doi.org/10.32983/2222-0712-2019-3-281-288

Fig.: 5. Bibl.: 17.

Skydan Oleh V. - Doctor of Sciences (Economics), Professor, Professor of the Department of Innovative Business and Investment Activities, Zhytomyr National Agroecological University (7 Staryi Blvd., Zhytomyr, 10008, Ukraine)

E-mail: skydanolegv@ukr.net

ORCID: http://orcid.org/0000-0003-4673-9620

Dankevych Vitalii Ye. - Doctor of Sciences (Economics), Associate Professor, Professor of the Department of International Economic Relations and European Integration, Zhytomyr National Agroecological University (7 Staryi Blvd., Zhytomyr, 10008, Ukraine)

E-mail:dankevych2017@gmail.com

ORCID: http://orcid.org/0000-0002-0522-2927

Researcher ID: $h$ ttp://www.researcherid.com/E-3739-2017

Dankevych Yevgen M. - Doctor of Sciences (Economics), Associate Professor, Professor of the Department of Environmental Safety and Environmental Economics, Zhytomyr National Agroecological University (7 Staryi Blvd., Zhytomyr, 10008, Ukraine)

E-mail:dankevych2020@gmail.com

ORCID: http://orcid.org/0000-0001-8337-5956

УДК 681.518.3.528

JEL Classification: Q13; R52

Скидан О. В., Данкевич В. Є., Данкевич Є. М. Сучасний стан використання космічних технологій для моніторингу ефективності землекористування

Метою статті є дослідження сучасного стану використання космічних технологій для моніторингу ефективності землекористування. Обгрунтовано, що в умовах глобалізації світової економіки відбувається діджиталізація та автоматизація виробничих процесів із використанням космічних технологій та багато інших інноваційних транссормацій, які варто ураховувати при здійсненні господарської діяльності, особливо в сільському господарстві. Доведено, що подальший розвиток аграрного сектора та сільськогосподарського землекористування необхідно планувати відповідно до стратегії інноваційного розвитку, яка включає: збільшення внеску науки і техніки у розвиток економіки землекористування; використання космічних
УДК 681.518.3.528

JEL Classification: Q13; R52

Скидан О. В., Данкевич В. Е., Данкевич Е. М. Современное состояние использования космических технологий для мониторинга эффективности землепользования

Целью статьи является исследование современного состояния использования космических технологий для мониторинга эффективности землепользования. Обосновано, что в условиях глобализации мировой экономики происходит диджитализация и автоматизация производственных процессов с использованием космических технологий и много других инновационных трансформаций, которые стоит учитывать при осуществлении хозяйственной деятельности, особенно в сельском хозяйстве. Доказано, что дальнейшее развитие аграрного сектора и сельскохозяйственного землепользования необходимо планировать в соответствии со стратегией инновационного развития, которая включает: увеличение вклада науки и техники в развитие экономики 
технологій для моніторингу ефрективності землекористування; підвищення конкурентоспроможності продукиії на світовому ринку за рахунок модернізації та автоматизації виробничих потужностей; широке запровадження технологій дистанційного зондування землі. обгрунтовано, що одним із напрямів залучення інноваційних розробок є сучасні космічні технології. Сучасний стан та тенденції використання космічних технологій для моніторингу ефективності землекористування розглянуто на рівні підприємства та держави. Проаналізовано запровадження в Україні сучасних космічних технологій для моніторингу землекористування (EOS Crop Monitoring, GIS Data). Доведено, що використання технологій космічного моніторингу дозволяє з високою точністю оцінити площу посівів, відстежувати стан рослин на всіх фазах росту, прогнозувати врожай на ранніх стадіях, контролювати агрооперації та інше. Доступ до супутникових даних за попередні роки та аналіз великих масивів інформації з використанням найновіших технологій дозволяють проводити оцінку вартості землі. Окреслено перспективні сектори землекористування, де мають бути застосовані сучасні космічні технології, а саме: наповнення Державного земельного кадастру, інвентаризація земель, відцифровування наявних даних, формування баз даних щодо земельних ресурсів. Запропоновано практичні рекомендації щодо використання космічних технологій для моніторингу ефективності землекористування, прогнозування врожаю та аналізу ціноутворення із використанням досвіду ЄС та США.

Ключові слова: сільськогосподарське виробництво, земельні ресурси, космічні технології, моніторинг, глобалізачія, ефективність, ГІСтехнології.

\section{Рис.: 5. Бібл.: 17.}

Скидан Олег Васильович - доктор економічних наук, професор, професор кафедри інноваційного підприємництва та інвестиційної діяльності, Житомирський національний агроекологічний університет (Старий бульвар, 7, Житомир, 10008, Україна)

E-mail: skydanolegv@ukr.net

ORCID: http://orcid.org/0000-0003-4673-9620

Данкевич Віталій євгенович - доктор економічних наук, доцент, професор кафедри міжнародних економічних відносин та європейської інтеграції, Житомирський національний агроекологічний університет (Старий бульвар, 7, Житомир, 10008, Україна)

E-mail: dankevych2017@gmail.com

ORCID: http://orcid.org/0000-0002-0522-2927

Researcher ID: http://www.researcherid.com/E-3739-2017

Данкевич Євген Михайлович - доктор економічних наук, доцент, професор кафедри екологічної безпеки та економіки природокористування, Житомирський національний агроекологічний університет (Cтарий бульвар, 7, Житомир, 10008, Україна)

E-mail: dankevych2020@gmail.com

ORCID: http://orcid.org/0000-0001-8337-5956 землепользования; использование космических технологий для мониторинга эффективности землепользования; повышение конкурентоспособности продукции на мировом рынке за счет модернизации и автоматизации производственных мощностей; широкое внедрение технологий дистанционного зондирования земли. Обосновано, что одним из направлений привлечения инновационных разработок являются современные космические технологии. Современное состояние и тенденции использования космических технологий для мониторинга эффективности землепользования рассмотрено на уровне предприятия и государства. Проанализированы введения в Украине современных космических технологий для мониторинга землепользования (EOS Crop Monitoring, GIS Data). Доказано, что использование технологий космического мониторинга позволяет с высокой точностью оценить площадь посевов, отслеживать состояние растений на всех фазах роста, прогнозировать урожай на ранних стадиях, контролировать агрооперации и прочее. Доступ к спутниковым данным за предыдущие годы и анализ огромных массивов информации с использованием новейших технологий позволяют проводить оценку стоимости земли. Определены перспективные сектора землепользования где должны быть применены современные космические технологии, а именно: наполнение Государственного земельного кадастра, инвентаризация земель, формирование баз данных по земельным ресурсам. Предложены практические рекомендации по использованию космических технологий для мониторинга эффрективности землепользования, прогнозирования урожая и анализа ценообразования с использованием опыта ЕС и США.

Ключевые слова: сельскохозяйственное производство, земельные ресурсы, космические технологии, мониторинг, глобализация, эффекктивность, ГИС-технологии.

Pис.: 5. Библ.: 17.

Скидан Олег Васильевич - доктор экономических наук, профессор, профессор кафедры инновационного предпринимательства и инвестиционной деятельности, Житомирский национальный агроэкологический университет (Старый бульвар, 7, Житомир, 10008, Украина)

E-mail: skydanolegv@ukr.net

ORCID: http://orcid.org/0000-0003-4673-9620

Данкевич Виталий Евгеньевич - доктор экономических наук, доцент, профессор кафедры международных экономических отношений и европейской интеграции, Житомирский национальный агроэкологический университет (Старый бульвар, 7, Житомир, 10008, Украина)

E-mail: dankevych2017@gmail.com

ORCID: http://orcid.org/0000-0002-0522-2927

Researcher ID: http://www.researcherid.com/E-3739-2017

Данкевич Евгений Михайлович - доктор экономических наук, доцент, профессор кафедры экологической безопасности и экономики природопользования, Житомирский национальный агроэкологический универcuтет (Старый бульвар, 7, Житомир, 10008, Украина)

E-mail: dankevych2020@gmail.com

ORCID: http://orcid.org/0000-0001-8337-5956
Problem statement. Digital technologies have made it possible to conglomerate a large amount of data into a single system as well as provided the access to them for a significant number of people. The times when there was a monopoly on information are becoming a thing of the past. Over the recent decades, high technologies in Ukraine have become largely used to solve tasks at the state level, and it was their capabilities that significantly increased the possibility to enhance the efficiency of economic activity and control production processes.
These trends are especially relevant for the agricultural sector and the development of land relations.

Transparent and effective land management is a prerequisite for the economic development of Ukraine and its territorial communities. Although Ukraine has a vast land resource of high quality, the productivity of its agricultural sector and the income of local communities from land ownership are significantly lower than in other countries. Without effective tools of land management, about 10.5 million hectares of agricultural 
land owned by the state and territorial communities is often a source of corruption. In particular, in case of more efficient land management, budget revenues of territorial communities can grow up to at least USD150 million compared to the current USD617 thousand. This in turn is an important factor in the success of the reforms launched in the country. Therefore, the issue of monitoring land use with the application of modern space technologies is a very important and promising research area.

Methodology. The theoretical and methodological basis of the study is the dialectical method of cognition of economic processes, the fundamental principles of modern economic theory, scientific works of domestic and foreign scientists considering the impact of economic globalization on the formation of land relations in agriculture and the use of GIS-technologies. The methodological background of the study is scientific methods of cognition based on a systems approach. To achieve the goal set, a number of general and special research methods are used: systems analysis; abstract logic methods; method of analogies.

Analysis of recent researches and publications. The first open geodata portal for communities GIS Data began to work in Ukraine [3]. There are a significant number of Internet resources that provide data on the current state of applying space technologies to monitor land use efficiency [1-2]. At present, many scientists are interested in studying this issue, including V. Zatserkovnyi, who analyzed the possibility for increasing efficiency of agricultural production due to applying GIS technologies in solving management tasks [4]. Moreover, the author paid attention to the issue of the application of geographic information systems and remote sensing systems for efficient land use [5]. V. Tyshkovets considered modern problems of land monitoring in Ukraine [6]. V. Schepak investigated the features of monitoring agricultural land use [7]. M. Malanchuk examined the specifics and current problems of soil monitoring in Ukraine [8]. Y. Petlyuk explored the legal aspects of land monitoring in Ukraine [9]. O. Dorosh studied the features of land inventory and methodological approaches to its implementation [10].

Land management is described in a number of course books and guidebooks under the editorship of V. Viun [13]. The reviewing of literary sources allows to state that it is precisely space technologies and, in particular, Earth Remote Sensing that make it possible to monitor the state of using land resources and conduct their continuous monitoring.

The analysis of publications [14-17] and normative legal documents [12] allows to identify the key issues that are a prerequisite for ensuring effective management of land resources in the short term. These are: providing a comprehensive land cadaster; ensuring simple and quick procedures in the field of land relations and exchange of data on land ownership by state bodies; developing the capacity of local communities for effective land management; transparency of land management data and analysis of these data in order to better formulate public policy in the agricultural sector. The implementation of this is also possible through the application of modern space technologies for monitoring land use.

Presentation of basic material of the research. The introduction of innovative space technologies will allow to effectively transform agricultural production, stimulate small and medium-sized enterprises and at the same time provide access to the world market, which is extremely important, given the existing resource potential. These actions will contribute to improving labor productivity, saving various types of resources, reducing losses and cost of food products, increasing volumes and enhancing efficiency of agricultural production.

The leading countries of the world can't afford not to develop space technologies, since the importance of this industry in the nationwide development is difficult to deny. For example, in 2017, the United States spent 0.248 \% of the federal budget on the development and support of the space industry, while Russia $-0.165 \%$, France $-0.105 \%$, China $-0.076 \%$. It should be noted that these countries have already carried out the diversification of the space industry, and as of 2017, developed several space programs: military, industrial, telecommunication, agricultural ones, programs for environmental monitoring, etc.

This distribution shows that information obtained from space is an important component in the development of these industries. As regards agriculture, in the EU countries, using this technology has replaced the work of field inspectors; it is from these data that decisions on the provision of subsidies are made. In the United States, satellite data are used to forecast crop yield and analyze pricing (Fig. 1).

In recent years, the trend of explosive development of the latest space technologies has become increasingly popular. Almost daily we hear about breakthrough projects that are implemented by ambitious scientists and engineers with the support of advanced countries or risky businessmen. Space is slowly becoming open not only to large corporations and states but also to small companies, universities, independent groups of scientists and students. And this is not just a trend - it is the realities of today.

Analyzing the scope of application of space technologies, it is worth mentioning that in the future they will be used to implement ambitious plans for the total coverage of our planet with the Internet through thousands of satellites, preparation for space travel, colonization of other planets, research on extraterrestrial civilizations, etc. In this context, we should take a closer look at the trends and plans for space exploration and the current role of our country in these processes.

The government adopted the concept of the space program of Ukraine for 2018-2022. During the five-year term, it is planned to attract UAH25 billion for the program. At the same time, the budget of the State Space Agency for 2018 is UAH248 million or 8.7 million dollars. This program defines the directions for the development of the space industry of Ukraine and the amount of its financing by the state. It is interesting that for the implementation of the previous program of 2013-2017 it was planned to attract UAH2.58 billion. This means that space financing should grow ten times.

The new concept aims to increase the efficiency of the existing space potential of the country and deepen international cooperation. In 2018-2022, the emphasis will be on Earth observation and telecommunications. For example, in 2019 it is planned to launch the first Ukrainian telecommunications satellite Lybid. The development of the satellite was envisaged 


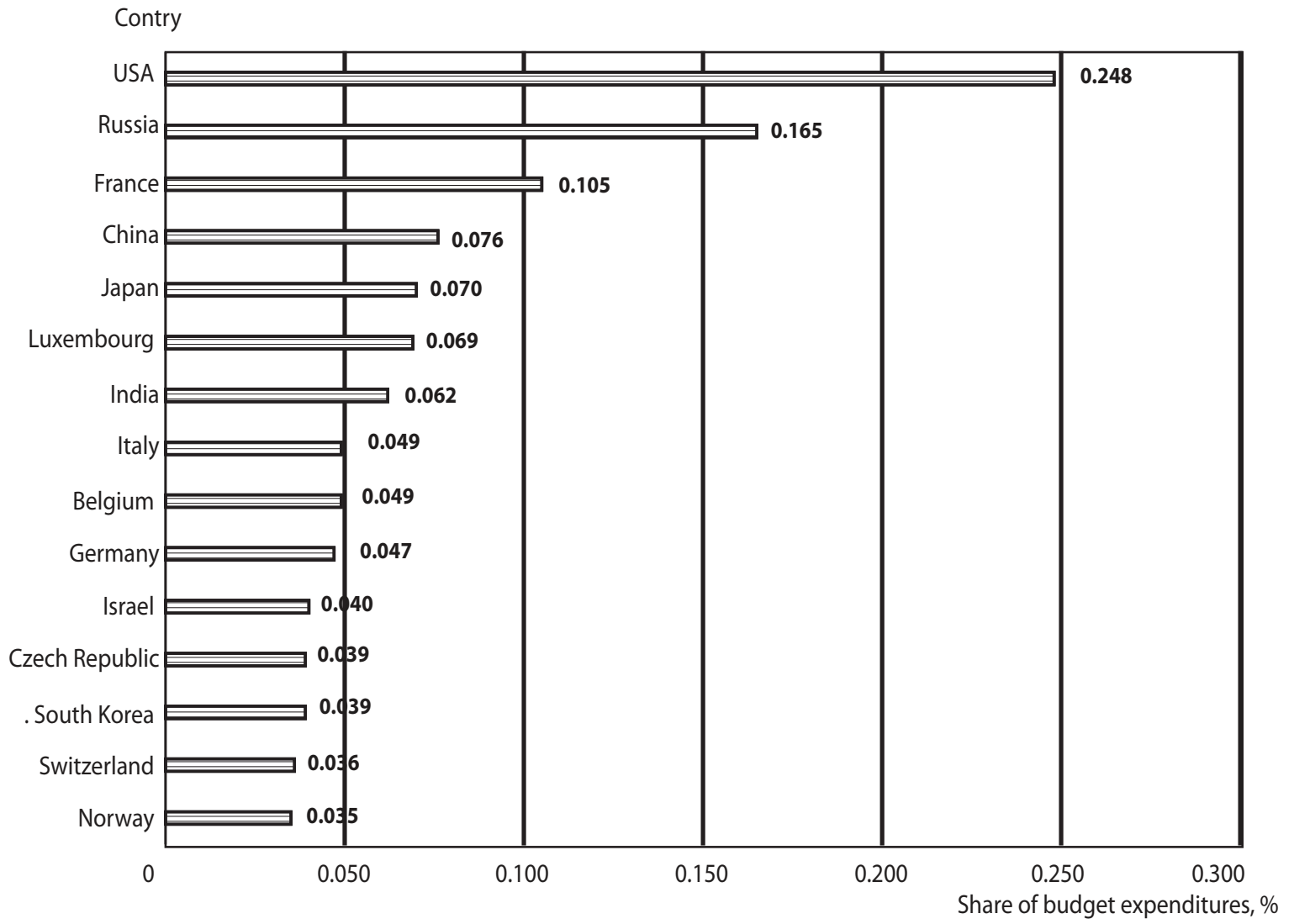

Fig. 1. Share of budget expenditures on the space sector in leading countries of the world, \%, 2017

Source: [17]

by the program for 2007-2011. Its launch date was repeatedly postponed. After the annexation of the Crimea by Russia, the satellite tracking and data acquisition station remained in the uncontrolled territory [17].

As for the expenditures on the space sector in other countries, the world record holder in terms of the budget is the NASA, which in 2018 received more than USD21 billion of financing. Other participants in the space services market have significant funds. For example, the budget of the International European Space Agency in 2018 amounted to almost USD6.5 billion [17].

In Ukraine, a promising area for using space technologies is the agricultural sector. Already today, a significant number of agricultural operations are carried out with the application of Earth Remote Sensing (ERS) (Fig. 2).

One of the prerequisites for the effective functioning of the domestic agricultural sector and the rational use of the existing land resources is the employment of modern technologies in this area. The current state of and trends in the application of space technologies to monitor land use efficiency will be examined in more detail at the level of enterprises and the level of the state as a whole.

The application of space technologies to monitor land use efficiency at the enterprise level. One of the manifestations of innovative development of the agrarian sector of the economy is the land-use technology called "precision farming". This technology began to actively develop in the EU Member States in the late 1990s and was recognized by the world agricultural science as quite effective, shifting agricultural business to a higher quality level. In fact, it is a set of measures that allows to accumulate objective information, analyze it and make prompt and effective decisions in the process of land use, ownership and disposal.

Corporate-type enterprises use the following precision farming technologies: global positioning systems (GPS-navigators, GLONASS), soil sampling systems, satellite and aerial photography, as well as special programs for GIS-based agricultural management (Fig. 3).

Equipment with elements of the precision farming technology is also used by domestic producers. Domestic enterprises, namely: A.T.K. LLC, Myronivsky Hliboproduct PJSC, Astarta-Kyiv LLC, TAKO PJSC, Nibulon JV LLC, Agro-Trade Company LLC, UkrAgroCom LLC, Agro-Soyuz LLC, Ukrzernoprom PJSC, Loture LLC are widely using computer modules intended for the control of fuel consumption, seeds, fertilizer application rate on their agricultural machinery. Modern ERS technologies allow to keep a record of all machinery of the enterprise, show their locations and efficiency of work.

In addition to improving the accuracy of work, the application of integrated control systems for intensive land use allows operators to pay more attention to their working machines, work at night and use modern machinery more efficiently. Sowing complexes equipped with satellite navigation enable carrying out agromonitoring and sowing with an accuracy within a centimeter, which is important for following the crop cultivation technology (Fig. 4). The computerization 


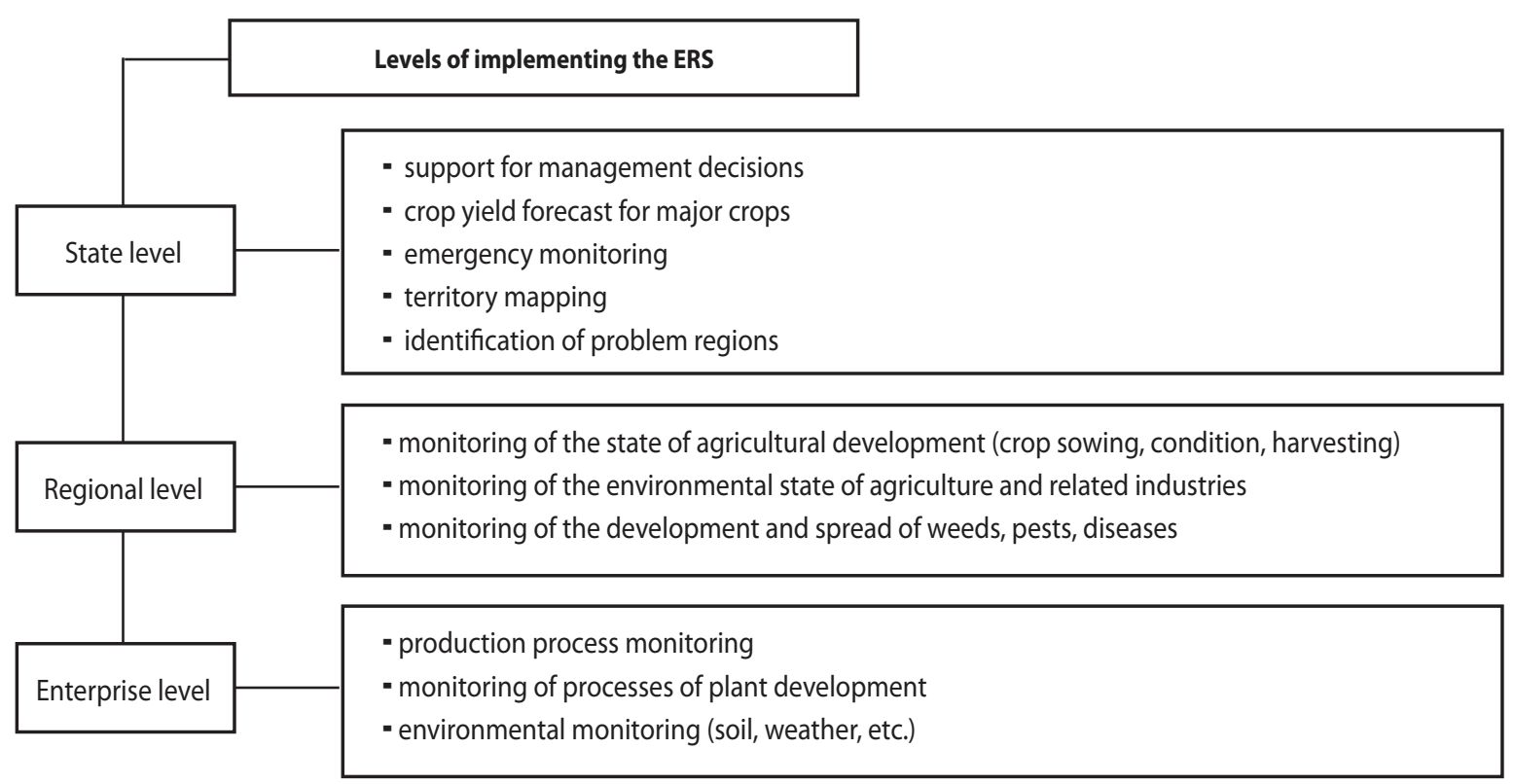

Fig. 2. Application of remote sensing technologies in the agricultural sector

Source: developed by the author

\begin{tabular}{|c|c|c|c|}
\hline \multicolumn{4}{|c|}{ Integrated Agricultural Control Systems (IACSs) } \\
\hline $\begin{array}{c}\text { Economic process control } \\
\text { systems (" } 1 C^{\prime \prime}, " A G R O L A B \text { ", } \\
\text { "M.E.Doc") }\end{array}$ & $\begin{array}{l}\text { Farming control systems } \\
\text { ("No-till","Auto Track") }\end{array}$ & $\begin{array}{c}\text { Production } \\
\text { control systems }\end{array}$ & $\begin{array}{c}\text { Logistics control systems } \\
\text { in enterprises }\end{array}$ \\
\hline $\begin{array}{l}\text { Makes it possible } \\
\text { to determine: } \\
\text { - place and type of work } \\
\text { of the motor vehicle; } \\
\text { - fuel consumption; } \\
\text { - kilometers traveled and } \\
\text { minimization of working } \\
\text { time; } \\
\text { - state of implementation } \\
\text { of business operations at } \\
\text { the enterprise }\end{array}$ & $\begin{array}{l}\text { Involves: } \\
\text { - forming the field work } \\
\text { plan; } \\
\text { - submitting reports on } \\
\text { technological } \\
\text { operations; } \\
\text { - monitoring accuracy of } \\
\text { farming operations; } \\
\text { - minimizing the cost of } \\
\text { fuel, seeds, fertilizers and } \\
\text { plant protection } \\
\text { products; } \\
\text { - forecasting the yield }\end{array}$ & $\begin{array}{l}\text { Involves: } \\
\text { - registering the weight of } \\
\text { the motor vehicle; } \\
\text { - binding the weight of the } \\
\text { vehicle to its license } \\
\text { number; } \\
\text { - tracking information in } \\
\text { the system; } \\
\text { - reducing expenses on } \\
\text { production registration; } \\
\text { - reducing production } \\
\text { costs and prime cost }\end{array}$ & $\begin{array}{l}\text { Involves: } \\
\text { - solving transport } \\
\text { problems related to } \\
\text { movement of goods } \\
\text { and movement of } \\
\text { agricultural machinery } \\
\text { between separate fields } \\
\text { during the implementa- } \\
\text { tion of business } \\
\text { operations }\end{array}$ \\
\hline
\end{tabular}

Fig. 3. Application of Integrated Agricultural Control Systems for intensive land use

Source: developed by the author

of combined harvesters makes it possible to obtain all the information necessary during threshing: productivity, moisture, threshing yield and grain loss, amount of threshed area per day or for the entire harvesting period.

Given the cost of space technologies for monitoring land use and difficult financial position of many domestic producers, the deployment of a set of software and hardware at the enterprise can be carried out in stages, with gradual installing of the necessary software components. Solving the problem of automation of planning, dispatching, accounting and control processes in agricultural production should be carried out comprehensively, with the application of geographic information systems, satellite navigation (GPS), systems of data transmission via GSM / GPRS channels, a computerized dispatch center and various sensors installed on agricultural machinery.

Analysis of the economic activities of Agrofirma Svitanok PSP, A.T.K. LLC, TAKO PJSC, Ukr-Agro RT LLC, Nibulon JV LLC suggests that modern technologies for minimizing soil cultivation ensure increasing labor productivity in agriculture; saving on combustive-lubricating materials, depreciation of machines and tractors, spare parts; and decreasing the total cost of 1 ha. 


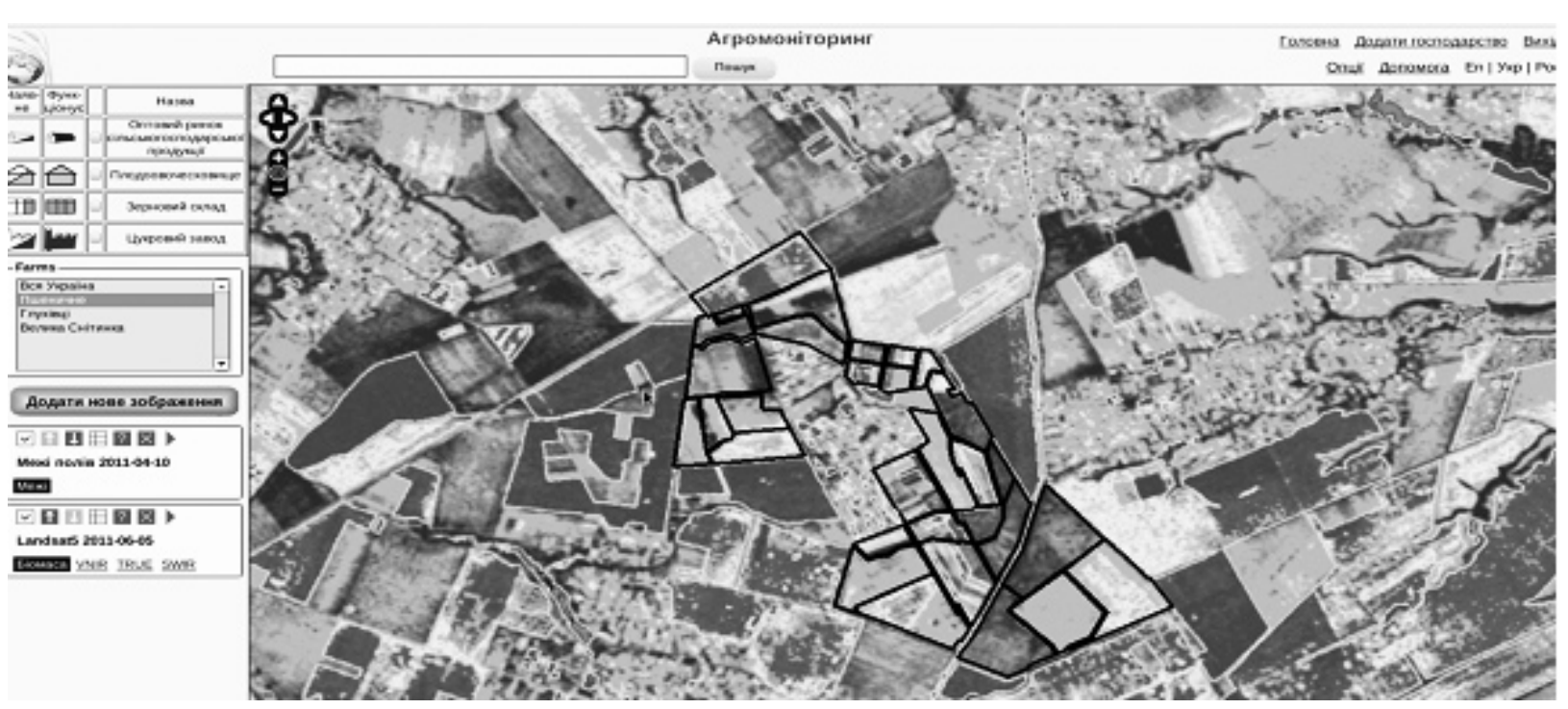

Fig. 4. Agricultural monitoring using Global Positioning Systems

Source: [17]

The application of space technologies to monitor land use efficiency at the state level. The development of space technologies for monitoring land use efficiency is facilitated by international programs that operate in Ukraine. For example, the World Bank, with financial support from the EU, launched a pilot project on farmland satellite monitoring in Ukraine.

As part of the 5-year program to improve transparency and efficiency of land asset management in Ukraine - Land Transparency, the project with the application of space technologies is being currently implemented in Lviv, Kyiv and Mykolaiv region by the American company EOS (Earth Observing System) that won the contract. Within the framework of the program, EOS, based on satellite monitoring data, conducted an analysis of the terrestrial vegetation cover. This allowed to create maps of agricultural crops, determine the exact boundaries of the fields, as well as identify all main types of vegetation cover in the three regions in the period 2016-2018.

The World Bank is joining the Earth Remote Sensing (ERS) project that will monitor crop rotation and yield. Also, ERS will make it possible to monitor soil erosion and logging, study the feasibility of introducing irrigation systems. This technology will improve community land registration and increase land rental income. Under the program, specialists want to combine several information resources into a single portal - Nsdi.land.gov.ua [1]. EOS has introduced a unified database that contains the information on crop areas and weather conditions in Ukraine over the past three years (Fig. 5). It will allow farmers to analyze crop conditions and take into account the specifics of a separate plot of land and the district as a whole for planning future work [2].

Integrated geoinformation technologies for agricultural production called Precision Farming are a tool that contributes to solving three main tasks that determine success in today's market: searching for timely and accurate information, making the right management decisions and implementing these decisions in practice.

The first open geodata portal for communities - GIS Data - began to work in Ukraine. It is a tool for smart community management containing more than 100 data sets from 40 sources and 13 tips for their application. The data sets include information on economic development, industry, recreational potential, construction, relevant and highly accurate data on soils, crops, even weather, etc. - all that each community needs for making various decisions and its further development.

It should be noted that all these data were scattered among different sources. To solve the problem of searching for a range of data on a specific geographical localization, the team of the E-Solutions for Communities project created the GIS Data Portal. It combines a simple rubric structured selection of geospatial layers and various analytical e-solutions aimed at innovative development of society and pumping up local budgets due to increasing land use efficiency.

Having implemented analytical e-solutions, most of which are built on the basis of the GIS Data Portal, communities receive tools that will help them increase their budget revenues, manage their assets efficiently, solve environmental problems, monitor the environment, forecast the development of adverse events (erosion, landslides, flooding, etc.), manage the network of social infrastructure, etc.

As the conducted studies show, in order to ensure the proper effectiveness of the state policy for land management in Ukraine, it is necessary to abundantly use the data of Earth remote Sensing and monitor land resources. Promising areas of land use where modern space technologies can be applied are as follows.

Filling the State Land Cadaster with correct data. The incomplete content of the State Land Cadaster, numerous errors in its data and lack of open access to them are a significant obstacle to ensuring effective land management.

Taking land inventory, including in the process of land transfer to the united territorial communities, as well as combining the inventory process with the land resource planning. Actually, the process of land transfer itself is a stimulus for taking its inventory, during which some errors made in the Cadaster are corrected.

Digitalizing all available data. Continuing the filling up of the Cadaster, digitalization of its data and the use of modern technologies, such as Earth Remote Sensing, mobile technolo- 


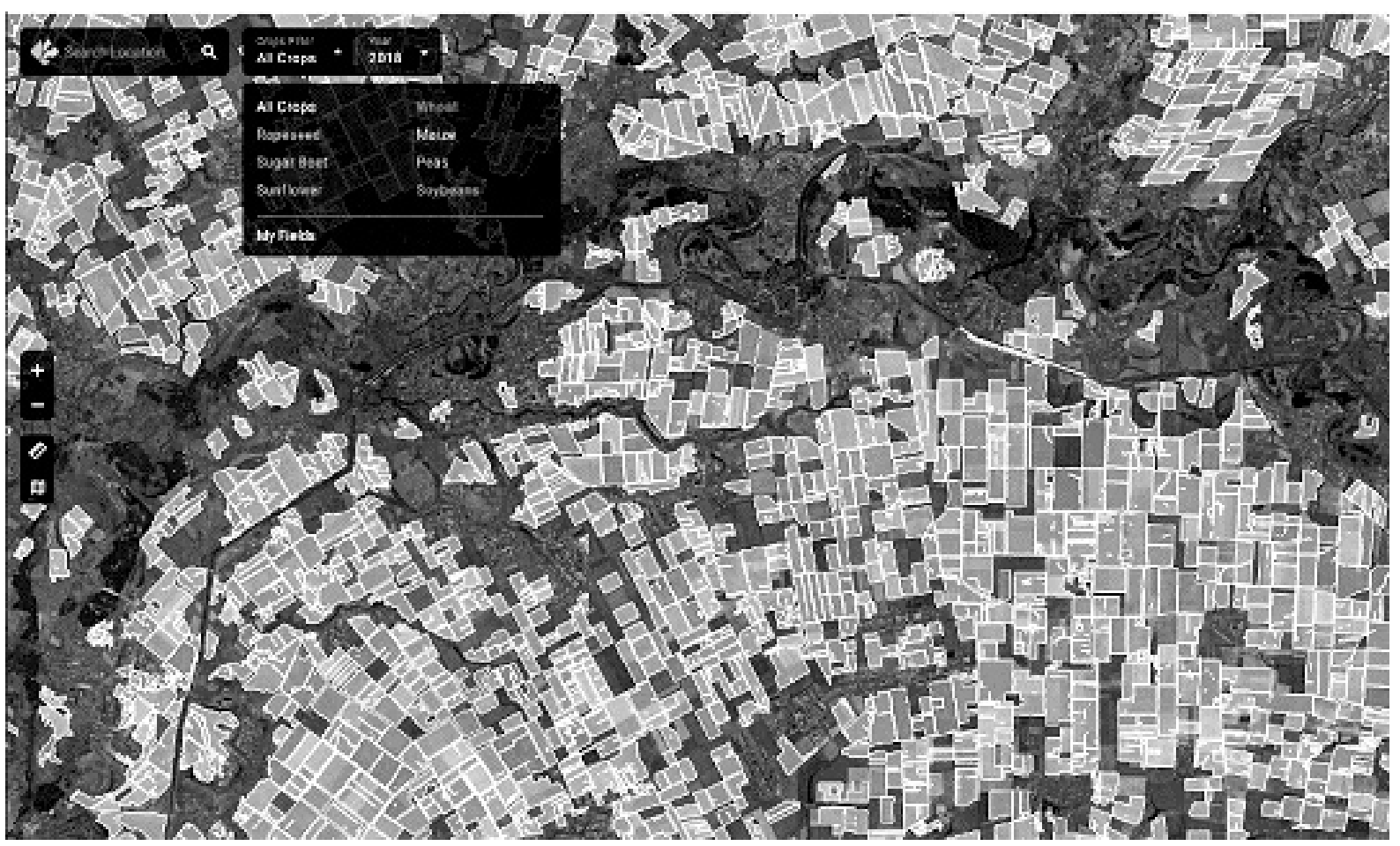

Fig. 5. Unified database on crop areas in Ukraine by EOS Crop Monitoring

Source: [2].

gies, will help to correct errors in the Land Cadaster, provide transparency in land relations, help strengthen protection of the rights of owners of land shares, and allow banks to use information about land resources owned / leased by borrowers, which means revitalizing bank lending to farmers. Finally, an important factor in ensuring effectiveness of land management is accessible, transparent, open and well-structured data.

Conclusions. Space technologies provide a wide range of opportunities for agricultural land use, including: identification and registration of crop areas; crop yield forecast; analysis of the crop conditions; estimation of crop areas; identification of areas requiring fertilizers, chemical weed and pest killers; control over crop rotations and quality of agrotechnical measures; identification of crop areas under risk of freeze damage; estimation of pasture areas; analysis of results of subsidizing; assessment of snow cover, humidity; identification of affected areas, etc.

The experience of other countries shows that the use of such information by an agricultural enterprise can improve land use efficiency. This is very promising. The point is that we will not only be able to observe space from the Earth but also to observe the Earth from space, using this data for the needs of the agricultural sector.

The use of geoinformation technologies in agriculture is possible both at the regional and state levels for vertical (between different management levels) and horizontal (between farms or organizations of the same level) coordination of actions. The most famous and effective providers of this service are the following companies: "Cropio" (USA / Germany), "eLeaf" (Holland), "PrecisionAgriculture" (Australia), "AstriumGeo" (France), "MapExpert" (Ukraine). Using these systems allows not only to quickly monitor the condition of fields but also to receive reports and messages on production in real time; forecast the yield of fields and the economy as a whole; receive related information on agricultural markets, currency quotes and prices of agricultural products on individual stock exchanges.

Today, in Ukraine, a big problem is that the access to a significant amount of information necessary for agricultural land use is limited. For example, the village council cannot see who owns a particular plot, which significantly complicates the adoption of any decisions on the development of rural territories. Therefore, it is necessary to provide access of any user in Ukraine to information on land resources and access of village councils to data on their land. In addition, the data sets collected by statistics bodies and accessible for monitoring and analysis (in particular, due to geodata) should be significantly expanded.

\section{LITERATURE}

1. За українським землеробством почали спостерігати 3 космосу // Економічна правда. URL: https://www.epravda.com. ua/news/2019/01/11/644220/

2. Супутники на службі в аграріїв: планування посівної за допомогою EOS Crop Monitoring. URL: https://landlord.ua/ news/tehnologii/suputnyky-na-sluzhbi-v-ahrariiv-planuvanniaposivnoi-za-dopomohoiu-eos-crop-monitoring/

3. Почав працювати перший портал відкритих геоданих для громад GIS Data. URL: https://selo.ua/ru/blog/pochavpracuvati-pershij-portal-vidkritih-geodanih-dla-gromad-gis-data

4. Зацерковний В. І., Кривоберець С. В. Аналіз можливості підвищення ефективності сільськогосподарського виробництва при застосуванні ГІТ у задачах управління. Вісник ЧДТУ. Сер. «Технічні науки». 2013. № 3 (67). С. 174-183. 
5. Зацерковний В. І. Геоінформаційні системи і системи дистанційного зондування землі в задачах ефективного землекористування. Математичне моделювання в економіці. 2014. Вип. 1. С. $40-48$.

6. Тишковець В. В., Опара В. М. Сучасні проблеми моніторингу земель в Україні. Харків : ХНАУ ім. В. В. Докучаєва, 2009. C. 126-134.

7. Щепак В. В. Экономическая модель системы мониторинга земель. Бізнес Інформ. 2016. № 11. С. 124-128.

8. Маланчук М., Панас Р. Сучасні проблеми здійснення моніторингу ґрунтового покриву в Україні. Геодезія, картографія і аерофотознімання. 2013. Вип. 78. С. 201-204.

9. Петлюк Ю. С. Правові аспекти здійснення моніторингу земель в Україні. Вісник Академії адвокатури України. 2011. № 2 (21). С. 246-247.

10. Дорош ОС. Інвентаризація земель: методичні підходи до її проведення. Агросвіт. 2015. № 11. С. 24-30.

11. Корнєєв Ю. В. Земельне право : навч. посіб. Київ : Центр учб. літ., 2011.248 с.

12. Земельний кодекс України : Закон України від 25.10.2001 № 2768+III / Верховна Рада України // Відомості Верховної Ради України. 2002. № 3-4. Ст. 27.

13. Управління земельними ресурсами : навч. посіб. / за ред. В. Г. В'юна. Миколаїв : Вид-во МФ НаУКМА, 2002. 316 с.

14. Dankevych V., Dankevych Y., Pyvovar P. Clustering of the international agricultural trade between Ukraine and the EU. Management Theory and Studies for Rural Business and Infrastructure Development. 2018. Vol. 40. No. 3. P. 307-319.

15. Dankevych Y., Dankevych V., Chaikin O. Ukraine agricultural land market formation preconditions. Acta Univ. Agric. Silvic. Mendelianae Brun. 2017. No. 65. P. 259-271.

16. Statistical Yearbook "Land Governance Monitoring in Ukraine:2016-2017».URL:http://www.kse.org.ua/en/researchpolicy/ land/governance-monitoring/yearbook-2016-2017/

17. BBC. Billions for Space: How Much Ukraine and the World Spends. URL https://www.bbc.com/ukrainian/features-45422875

\section{REFERENCES}

"BBC. Billions for Space: How Much Ukraine and the World Spends". https://www.bbc.com/ukrainian/features-45422875

Dankevych, V., Dankevych, Y., and Pyvovar, P. "Clustering of the international agricultural trade between Ukraine and the EU". Management Theory and Studies for Rural Business and Infrastructure Development, vol. 40, no. 3 (2018): 307-319.

Dankevych, Y., Dankevych, V., and Chaikin, O. "Ukraine agricultural land market formation preconditions". Acta Univ. Agric. Silvic. Mendelianae Brun, no. 65 (2017): 259-271.

Dorosh, O. S. "Inventaryzatsiia zemel: metodychni pidkhody do yii provedennia" [Land inventory: methodological approaches to its implementation]. Ahrosvit, no. 11 (2015): 24-30.
Kornieiev, Yu. V. Zemelne pravo [Land Law]. Kyiv: Tsentr uchb. lit., 2011.

[Legal Act of Ukraine] (2001).

Malanchuk, M., and Panas, R. "Suchasni problemy zdiisnennia monitorynhu gruntovoho pokryvu v Ukraini" [Current problems of soil cover monitoring in Ukraine]. Heodeziia, kartohrafiia i aerofotoznimannia, no. 78 (2013): 201-204.

"Pochav pratsiuvaty pershyi portal vidkrytykh heodanykh dlia hromad GIS Data" [The first portal for open geodata for GIS Data communities has started operating]. https://selo.ua/ru/blog/ pochav-pracuvati-pershij-portal-vidkritih-geodanih-dla-gromadgis-data

Petliuk, Yu. S. "Pravovi aspekty zdiisnennia monitorynhu zemel v Ukraini" [Legal aspects of land monitoring in Ukraine]. Visnyk Akademii advokatury Ukrainy, no. 2 (21) (2011): 246-247.

"Suputnyky na sluzhbi v ahrariiv: planuvannia posivnoi za dopomohoiu EOS Crop Monitoring" [Farmers Satellites: Sowing Planning with EOS Crop Monitoring]. https://landlord.ua/news/ tehnologii/suputnyky-na-sluzhbi-v-ahrariiv-planuvannia-posivnoi-za-dopomohoiu-eos-crop-monitoring/

Shchepak, V. V. "Ekonomicheskaya model sistemy monitoringa zemel" [Economic model of land monitoring system]. Biznes Inform, no. 11 (2016): 124-128.

Statistical Yearbook "Land Governance Monitoring in Ukraine: 2016-2017". http://www.kse.org.ua/en/researchpolicy/ land/governance-monitoring/yearbook-2016-2017/

Tyshkovets, V. V., and Opara, V. M. Suchasni problemy monitorynhu zemel $v$ Ukraini [Current problems of land monitoring in Ukraine]. Kharkiv: KhNAU im. V. V. Dokuchaieva, 2009.

Upravlinnia zemelnymy resursamy [Land Management]. Mykolaiv: Vyd-vo MF NaUKMA, 2002.

"Za ukrainskym zemlerobstvom pochaly sposterihaty z kosmosu" [Ukrainian agriculture began to be observed from space]. Ekonomichna pravda. https://www.epravda.com.ua/ news/2019/01/11/644220/

Zatserkovnyi, V. I. "Heoinformatsiini systemy i systemy dystantsiinoho zonduvannia zemli $v$ zadachakh efektyvnoho zemlekorystuvannia" [Geoinformation systems and systems for remote sensing of land in problems of effective land use]. Matematychne modeliuvannia v ekonomitsi, no. 1 (2014): 40-48.

Zatserkovnyi, V. I., and Kryvoberets, S. V. "Analiz mozhlyvosti pidvyshchennia efektyvnosti silskohospodarskoho vyrobnytstva pry zastosuvanni HIT u zadachakh upravlinnia" [Analysis of the possibility of increasing the efficiency of agricultural production in the application of GIT in management tasks]. Visnyk ChDTU. Ser. «Tekhnichni nauky», no. 3 (67) (2013): 174-183.

Стаття надійшла до редакції 07.08.2019 